\section{Housing as urbanism: A policy to discourage urban sprawl and provide well-located and affordable housing in South Africa}

\author{
Brendon van Niekerk
}

Peer reviewed and revised October 2018

*The authors declared no conflict of interest for this title or article

\begin{abstract}
The concept of 'housing as urbanism' considers the social, political and economic components of housing, which, in reality, translates to housing that is closer to employment, municipal services, public spaces, healthcare, schooling facilities and social services, while also providing the household with the physical infrastructure necessary for a good quality of life. These considerations have not been included in the mass roll-out of low-income housing programmes by the South African government to date. A series of case studies show that, in South Africa, a more compact urban form does not necessarily lead to one that is less expensive than a sprawled urban form, due to infrastructure thresholds, capacities, location, land-use mix, and density variations over time and space. Due to the complex interrelations between land values in space, the costs of buildings and urban services, the relative cost of transport and the excess capacities in infrastructure systems, a simple dichotomous 'sprawled' versus 'compact' approach to housing location and urban development is not appropriate. Investigations of individual sites need to be performed, in order to understand the social, political and economic benefits, which will accrue to the households from their location in the city. The case studies also indicate that, over the long term, the overall cost of housing developments that are better located, subscribing broadly to the principles of 'housing as urbanism', is likely to be less expensive to municipalities and the development's residents than poorly located, sprawled housing developments. Decisions taken which consider the principles of 'housing as urbanism' can help create a more efficient urban form, freeing up resources for both urban residents and public-sector organisations.
\end{abstract}

Keywords: Affordable housing, housing as urbanism, fiscal impact study, urban efficiency, urban sprawl

\section{BEHUISING AS STEDELIKHEID: 'N BELEID OM STEDELIKE UITBREIDING TE ONTMOEDIG EN GOED GEVESTIGDE EN BEKOSTIGBARE BEHUISING IN SUID-AFRIKA TE BIED}

Die konsep 'behuising as stedelikheid' sluit in die sosiale, politieke en ekonomiese komponente van behuising, wat in werklikheid verwys na behuising naby aan werksplekke, munisipale dienste, openbare ruimtes, gesondheidsorg, skoolgeriewe en maatskaplike dienste, terwyl dit ook voorsiening maak vir die huishouding se fisiese infrastruktuur wat nodig is vir 'n goeie lewensgehalte. Tot op hede is hierdie oorwegings nie ingesluit in die massa-ontplooiing van lae-inkomste behuisingsprogramme deur die Suid-Afrikaanse regering nie. Gevallestudies toon dat 'n kompakte stedelike vorm in Suid-Afrika nie noodwendig lei tot een wat goedkoper is as 'n verspreide stedelike vorm nie, as gevolg van infrastruktuurdrempels, kapasiteite, ligging, landgebruiksmengsel en digtheidsvariasies oor tyd en ruimte. As gevolg van die komplekse interverwantskappe tussen grondwaardes in die ruimte, die koste van geboue en stedelike dienste, die relatiewe koste van vervoer en die oormatige kapasiteit in infrastruktuurstelsels, is 'n eenvoudige digotome 'uitgespreide' teenoor 'kompakte' benadering tot behuisingsligging en stedelike ontwikkeling nie gepas nie. Ondersoeke van individuele terreine moet uitgevoer word ten einde die sosiale, politieke en ekonomiese voordele wat uit die ligging van behuisingsontwikkelings voortspruit, te verstaan. Die gevallestudies dui ook daarop dat, oor die lang termyn, die algehele koste van behuisingsontwikkelings wat beter geleë is, en wat die beginsels van 'behuising as stedelikheid' onderskryf, waarskynlik goedkoper sal wees vir munisipaliteite en hul inwoners as dié van swak geleë, ontwikkelde behuisingsontwikkelings. Besluite gegrond op die beginsels van 'behuising as stedelikheid' kan help om 'n doeltreffender stedelike vorm te skep, wat hulpbronne vir beide stedelike inwoners en openbare sektor-organisasies vrystel.

Sleutelwoorde: Bekostigbare behuising, behuising as stedelikheid, fiskale impakstudie, stedelike doeltreffendheid, stedelike uitbreiding

\section{MATLO MORERONG WA HO ETSA MOTSE SETOROPO: MOLAWANA BAKENG SA HO SE KGOTHALLETSE TSHUBUHLELLANO / HO PETETSANA (SPRAWL) LE HO NEHELANA KA MATLO DIBAKENG TSE LOKILENG, HAPE E LE MATLO A KGONANG HO LEFELLWA AFRIKA BORWA}

Kgopolotaba ya "ho etsa matlo morerong wa ho etsa motse setoropo" e elahloko dintlha tsa botho, dipolotiki le moruo, tseo bophelong di fetohang ho ba matlo a leng haufinyanya le mesebetsi, ditshebeletso tsa masepala, dibaka tsa batho, bophelo bo botle, disebediswa tsa dikolo le ditshebeletso tsa batho, ha ka lehlakoreng le leng hape di fa malapa meralo ya motheo (infrastructure) e hlokahalang bakeng sa bophelo bo nang le boleng. Dikelohloko tsena ha di a kenyelletswa programong/lenaneong la mmuso wa Afrika Borwa wa palo ya matlo a fumanwang ke bongata ba batho ba fumanang moputso o tlase ho fihlela hajwale. Tlhatlhamano ya dithuto tsa mehlala (case studies) di bontsha hore Afrika Borwa, mofuta o monyane wa toropo hase hakaalo o etsang mofuta o leng tjhipi ho feta mofuta o petetsaneng ka lebaka la meralo ya motheo ya mehato e itseng, bokgoni, sebaka, tshebediso e kopaneng ya lefatshe le diphapang tsa teteano hodima nako le sebaka. Ka lebaka la dikamano tse kopakopaneng pakeng tsa boleng ba lefatshe dibakeng, theko ya meaho le ditshebeletso tsa toropong, theko e tlwaelehileng ya transporoto le bokgoni bo eketsehileng ba mokgwa wa tshebetso wa meralo ya motheo; karohano e bonolo ya dibaka kgahlanong le tshebediso ya matlo ma mannyane sebakeng le ntshetsopeleng ya toropo ha di a tshwaneleha. Dipatlisiso sebakeng ka seng di tlamehile di etswe hore ho utlwisiswe melemo ya botho, polotiki le moruo, mme di tla eketseha bakeng sa malapa ho tswa dibakeng tsa bona metsemeholong. Dithuto tsa mehlala hape di bontsha hore, nakong e telele, thekokakaretso ya dintlafatso tsa matlo dibakeng tse hantle, tse amohelang melaong ya "bodulo phetholelong ya 
motse setoropo" ka botlalo; e ka ba theko e tlase bakeng sa bommasepala le ho badudi ba intlafaletsang matlo a bona, ho e na le dintlafatsotso tsa bodulo dibakeng tse seng ntle, tse qaqolohaneng. Diqeto tse nkilweng, tse elang hloko "bodulo phetholelong ya motse setoropo" di ka thusa ketsong ya mokgwa o sebediswang wa toropo, moo mehlodi/disebediswa di entsweng mahala bakeng sa badudi ba toropong le mekgatlo lekaleng/sektareng ya batho bohle ka ho tshwana.

\section{INTRODUCTION}

South African cities are sprawled and racially segregated as a result of apartheid and the government's misguided attempts at trying to house low-income urban residents (Harrison \& Todes, 2013). The current urban form is socially, environmentally, politically and financially unsustainable (Harrison \& Todes, 2013). Extensive research has shown this to be true. However, there still appears to be a pervasive approach to housing as a physical entity, without considering the multiplicity of housing as a social, physical and economic entity. The concept of 'housing as urbanism' could assist in changing the perceptions of all housing, particularly low-income housing. Housing is a constituent component of urbanity; hence, housing should be viewed as 'urbanism'. The concepts of housing and urbanism are complex and multifaceted, consisting of social, physical and economic components. When these components of housing are considered together, housing and low-income housing, in particular, are likely to enable residents to enjoy an improved quality of life.

Research on the impact of urban sprawl on governmental and nongovernmental actors has shown that, generally, urban sprawl is not a desirable outcome from an environmental, social and economic perspective. This research has been widely conducted in South Africa, and the promotion of compact cities is almost omnipresent in South African planning law (Harrison \& Todes, 2013); yet its implementation has been poor (Turok \& Parnell, 2009). It appears that the creation of centrally located low-income housing is not a priority of government in South African cities. The recent sale of Tafelberg Site, a piece of provincially owned, well-located land near a private school in Cape Town, is a poignant reminder of the intersection of the power of capital, the interests of private developers, and the mandate of governmental actors.

This article aims to show that welllocated housing broadly conforms to the principles of 'housing as urbanism', is more affordable for governmental and non-governmental parties over the long term, and should thus be promoted. The up-front capital cost savings achieved by the housing developer (either private or government) when building housing developments on cheap, peripheral land is adversely transferred to the end user over time, particularly in the form of the costs of public transport, and adversely transferred to the municipality and State in the form of public transport subsidies and the costs of infrastructure network expansion. The extent to which this finding could be linked to the concept of 'housing as urbanism' is also investigated.

This article focuses on urban sprawl and its effect on housing as a constituent component of urbanism. It does not address Urban Design theory, but contextualises the interrelationships between housing, employment and nodes of urban amenities in space, with an emphasis on urban efficiency.

\section{HOUSING AS URBANISM}

Housing consists of a physical entity as well as a social, economic and political function (Madden \& Marcuse, 2016). The pervasive, narrow perception of housing as shelter has led to the creation of residential areas with very low social value to the inhabitants of the area (Ferrari, 2015) and perpetuated inequalities (Cociña, 2017). Housing, housing policies, and policies that indirectly impact on housing should, therefore, not be viewed as creating housing as a physical shelter. They must be considered to be the constituent components in the production of cities and thus the creation of urbanism. ${ }^{1}$

Urbanism is a concept with many different meanings, primarily due to the many complex social, cultural, political and physical interactions occurring within cities. Urbanism represents an evolution of normative ideas that have been occurring since the nineteenth century (Talen, 2006). The term is often attributed to Wirth (1938) who used the term to describe a way of living in an urban area. Urbanism (in particular, scholars and followers of 'New Urbanism') promotes the principles of a planned environment that is diverse in use, walkable, has sufficient public space, public transport access, densities creating a vibrant economy, and a safe, natural and pollution-free environment (Duany, Plater-Zyberk \& Speck, 2000; Talen, 2005; Congress of the New Urbanism, n.d.). Urbanism is also a set of tools and practices that increase connectivity (Fiori, 2013), thus altering the current state of many cities, and social policies, in urban areas globally (Fiori \& Brandão, 2010).

The conceptualisation of "housing as urbanism' is to recognise the multiple roles housing plays in the city as an intervention, both in urban space and in people's lives. The multitude of associated complexities include, but are not limited to, issues of housing as a right, the complexities of the land and housing markets (the materiality of housing), the multiscalarity of housing production (the social aspect of housing), and the multidimensional processes involved in housing (the political aspect of housing) (Cociña, 2017). There are also other complexities of housing: housing may increase the disposable income of a family; prevent material deprivation; increase

\footnotetext{
There is a debate regarding terms used to describe the principles of urbanism. This includes 'new urbanism', 'traditional urbanism', 'neo-traditional development', 'transit-oriented development', and 'smart growth'. There is a significant overlap between the terms used and the ideologies they contain. In this article, the term 'urbanism' encompasses most of the ideas contained in the different schools of urbanism.
} 
employment prospects; protect from environmental impacts, and improve the inhabitants' physical safety (Moser \& Dani, 2008; Birch, 2015); housing is also often the largest economic burden for those who own or use it (Madden \& Marcuse, 2016). The inherent multiplicity of housing is important when considering 'housing as urbanism', particularly state-led, low-income housing programmes that frequently have a quantitative target, and, therefore, frequently do not consider the multiplicity of poverty in the design and roll-out of housing programmes. Access to housing can thus either mitigate or exacerbate poverty (see Alkire, Foster, Seth, Santos, Roche \& Ballon, 2015).

The term housing should be viewed as both a noun and a verb when considering its role in urbanism (Martin, Moore \& Schindler, 2015), as this will help one conceive of the multiple complexities of housing. This echoes the sentiment of Turner (1976: 4), expressed by Ward in the preface to Housing by people: Towards autonomy in building environments: "The important thing about a house is what it does in the life of the dwellers rather than what it physically is." A house can either improve the life of the inhabitants or disadvantage them. These complexities are important to understand when designing a housing programme.

\section{URBAN SPRAWL}

Many impacts and costs occur as a result of urban sprawl, including social costs (see Putnam, 2000; Todes, 2003); environmental costs (see Dunn, 1983; Johnson, 2001; McKinney, 2002; Wilson \& Chakraborty, 2013); health costs (see McKee, 2003; Sturm \& Cohen, 2004), and economic costs. These will be dealt with in Section 5.2. The relationship between urbanism and urban sprawl will also be described.

\subsection{A brief introduction to urban sprawl}

Urban sprawl is a phrase used to capture many different aspects of contemporary urban morphology.
Audirac, Shermyen and Smith (1990: 470) write that "definitional ambiguities haunt the literature on urban sprawl", and Bhatta, Saraswati and Bandyopadhyay (2010) affirm that this has not changed in the twenty years between the authorship of the two papers. Galster, Hanson, Ratcliffe, Wolman, Coleman and Freihage (2001) reviewed an extensive amount of literature and identified the four main characteristics of urban sprawl: the patterns of land-use; the processes of land development; the causes of particular land-use behaviours, and the consequences of land-use behaviours.

If one is to attempt to navigate the definitional minefield in order to define urban sprawl, a definition was put forward by Altshuler and Gomez-lbanz (1993: 67): "continuous low-density residential development on the metropolitan fringe, ribbon low density development along major suburban highways, and development that leapfrogs past undeveloped land to leave a patchwork of developed and undeveloped tracts". This definition limits the single land use separated from other land uses to residential, which may not always be the case (see Burchell \& Listokin, 1978; Cervero, 1991, cited in Galster et al., 2001). A conceptual definition, which arose out of Galster et al. (2001), is "sprawl [as a noun] is a pattern of land use in a UA [urban area] that exhibits low levels of some combination of eight distinct dimensions: density, continuity, concentration, clustering, centrality, nuclearity, mixed uses, and proximity" (Galster et al., 2001: 685). This very broad and cumbersome definition highlights the many possible characteristics of urban sprawl.

\subsubsection{Deconstructing urban sprawl and urbanism in the Global South versus the Global North}

Urban sprawl in the Global North ('developed countries') and the Global South ('developing countries') exhibits some similarities and some very significant differences. In the Global North, referred to as the "Euro-American Model", urban sprawl is characterised by car-centric, suburban developments that are predominately mono-functional and far dispersed from one another (Dieleman \& Wegener, 2004), consisting of single-family homes (Leichenko \& Solecki, 2005) and based along highway infrastructures (Litman, 2015). Urban sprawl in the Global South can exhibit these characteristics, particularly in cities with a buoyant, car-owning, middle-class population seeking a higher quality of life on the urban edge (Leichenko \& Solecki, 2005). This is often coupled with an urge for the middle-class to separate themselves from the urban poor (Leichenko \& Solecki, 2005). Cities in the Global South, however, can also have urban sprawl dominated by informal areas, high density, unplanned settlements, and slumlike conditions (Bolay, 2006). Given that there is no comprehensively agreed upon definition, it is no surprise that the exact characteristics and causes of urban sprawl vary between the Global North and the Global South (Bekele, 2005).

The compact city is often presented as a universally valid concept, regardless of its context. It has been argued that the compact city paradigm is an "imperialist Global North perspective" (Brown, 2017: 5), which shows the power of Northern theorists based on "authoritative knowledge and their prevailing agendas" (Brown, 2017: 9). Using Derrida's principles of deconstruction, Brown (2017) reduces the basis of the compact city argument to the following assumptions: suburbanization is synonymous with low-density 'urban sprawl'; cities can and should be contained; the green agenda prevails, and cities are formal entities amenable to modern planning systems. The deconstructive analysis shows that there are significant differences between the Global North and the Global South when the assumptions themselves are considered, and that theorists may often overlook these contextual differences when conceptualising new ideas (Watson, 2008). There has been a move towards a Southern epistemology of planning that takes 
into account the survival strategies of the urban poor and engages with informality (Harrison, 2006, cited in Brown, 2017). It is unlikely that this new epistemology is being put into practice at the moment (see Angel, Parent, Civco \& Blei, 2011; Odendaal \& McCann, 2016). However, the concept of 'housing as urbanism' may work within the current planning paradigm, and the financial and social logic of municipal governance in South Africa.

\subsection{The relationship between urban sprawl and urbanism}

The concepts of urban sprawl and urbanism suffer from similar problems, whereby the definitions for both vary. Due to the lack of a coherent definition of urban sprawl and urbanism, the relationship between the two can vary. The main areas of contention between the concepts of urban sprawl and urbanism are briefly summarised in Table 1.

The generalised definition proposed in the previous sections indicates that there would be a negative correlation between urban sprawl and urbanism, except in the rare circumstances where urban expansion is designed with the intention of creating an urbanist area, as is the case in Cornell, Toronto (see Skaburskis, 2006).

\section{CHARACTERISTICS OF PRIMARY SOUTH AFRICAN CITIES}

There is a vast amount of literature on the morphology and planning ideologies of South African cities, the general consensus being that South African cities are spatially fragmented, unequal and sprawled. This section briefly describes different characteristics of South African cities, with a focus on how these relate to the principles of urban sprawl and urbanism.

\subsection{Urban morphology}

The morphology of South African cities has been called one of the most visible and enduring physical legacies of the apartheid era (Du Plessis \& Boonzaaier, 2015). South African cities are characterised by a fractured spatial make-up, substandard public transport systems, and peripheral low-income settlements made up of generally substandard and inappropriate housing (Richards, O'Leary \& Mutsonziwa, 2007). This 'apartheid city' structure is a "political economy of space" (South African Cities Network, 2004: 24), whereby there was deliberate exclusion based on race, and a political economy that benefited the few to the detriment of the majority. South African cities have also been called exclusionary cities

Table 1: $\quad$ Summary of the differences between urban sprawl and urbanism

\begin{tabular}{|c|c|c|}
\hline & Urban sprawl & Urbanism \\
\hline $\begin{array}{l}\text { Accessibility } \\
\text { and transport }\end{array}$ & $\begin{array}{l}\text { High use of private vehicles; generally } \\
\text { low levels of public transport; high } \\
\text { prevalence of highway infrastructure }\end{array}$ & $\begin{array}{l}\text { Associated with a provision of high } \\
\text { speed, efficient public transport; high } \\
\text { levels of pedestrian and cycling activity }\end{array}$ \\
\hline $\begin{array}{l}\text { Multifunctional } \\
\text { land use }\end{array}$ & Singular (generally residential) land use & Multifunctional land uses \\
\hline Density & $\begin{array}{l}\text { Generally low density in Global North; } \\
\text { can have high density in Global South }\end{array}$ & Associated with higher densities \\
\hline Continuity & $\begin{array}{l}\text { Characterised by development that } \\
\text { leapfrogs over undeveloped land }\end{array}$ & $\begin{array}{l}\text { Generally consists of continuous } \\
\text { development }\end{array}$ \\
\hline
\end{tabular}

Sources: Author's own; Altshuler \& Gomez-lbanez, 1993; Duany, Plater-Zyberk \& Speck, 2000; Dieleman \& Wegener, 2004; Galster et al., 2001

based on the peripheral location of many poor urban residents (South African Cities Network, 2016).

South African cities have made significant progress in terms of the provision of services over the past 20 years (Turok \& BorelSaladin, 2014; Palmer, Parnell \& Moodley, 2017). In urban areas, water and electricity provision is nearly universal; adequate solid waste solutions exist almost everywhere, and most of the areas have adequate paved roads, with adequate sanitation services being the least pervasive of the networked infrastructure services (StatsSA, 2012).

South Africa has a "formidable land administration system and a strong land rights base" in both urban and rural areas (Napier, 2007: 2), although there are still high levels of exclusion from the formal land market in cities. The informal land market is vibrant and provides an alternative for the acquisition of property or for the provision of rental opportunities. This informal land market can operate in well-located or peripheral areas (Napier, 2007: 2). Steep increases in the cost of land and housing over the past 20 years have forced the lower income segment of the population into informal transactions, where the increases in cost have been less significant (Harrison \& Todes, 2013). The formal market is driven by an economic and legal logic, whereas the informal market is driven by a different logic, one that is primarily social, with social networks and community management playing an important role (Nell, Gordon \& Bertoldi, 2004; Watson 2006; Urban LandMark 2010; Urban LandMark 2011c, cited in Hogarth, 2015).

In some ways, the post-apartheid era saw a consolidation of the apartheid city structure. The Reconstruction and Development Programme (RDP) housing programme was a state-led, free housing scheme. It led to further urban sprawl and concentration of the urban poor on peripheral, poorly serviced land (Napier, 2007; Pieterse, 2009). The RDP had a 
policy on fixed plot sizes, thus leaving land cost and housing typology the predominant factors in the provision of housing (Dewar, 2000; Bertaud, 2009). This housing policy, combined with the relatively low impact of planning policies, has led some academics to believe that South African cities are as fragmented and segregated as they were at the dawn of democracy in 1994 (Du Plessis \& Boonzaaier, 2015). Recently, however, there has been a significant policy move towards sustainable urban integration and densification in the newest government policy position on urban areas, the Integrated Urban Development Framework (IUDF) (Ministry of Cooperative Governance and Traditional Affairs, 2016). The logic for a move towards densification and compaction appears to be informed by social, environmental and redistributive economic arguments. Harrison and Todes (2013) argue that the overriding rationale for the move towards integration and densification is to improve the urban poor's access to the 'urban advantage'. Planning laws in South Africa seem to have had hardly any impact on the reversal of the spatial structure of the apartheid city, and any positive changes in the structure of the city are more likely to be as a result of the dismantling of statutory apartheid rather than because of proactive government planning policies (Harrison \& Todes, 2013).

\subsection{Urban economies and their interactions with space}

Due to the constitutional separation of the powers and functions of different levels of government (RSA, 1996), national government can impose little on local government in terms of the restructuring of the urban space economy.

At the city level, the national government led a mass roll-out of RDP housing manifested as peripherally located housing, even though the normative notions of densifying and improving the fragmented and sprawling character of South African cities are prevalent in the National Development Plan
2030 (National Planning Commission, 2012) and the IUDF, which sets out the national government's policy direction on urban areas (Ministry of Cooperative Governance and Traditional Affairs, 2016).

Economic distributions within South African cities themselves are highly unequal. Settlements of the urban poor are generally located far from economic opportunities. This has led to pockets of wealth and poverty, thus reinforcing inequality and further burdening poor households (see Turok, 2001; Turok \& Watson, 2001; Harrison \& Todes, 2013; Urban LandMark, 2011a, cited in Hogarth, 2015). In addition, developments driven by the formal private sector perpetuate this fragmented space economy, as they cater to the needs of the market (Hogarth, 2015). Cities in South Africa have attempted to address these private developers' interests by creating policies that attempt to target private development in certain areas. Examples of these are Urban Development Zones in Cape Town, the Corridors of Freedom in Johannesburg, and a variety of tax-benefit planning tools in other cities. Broadly, it appears that there have been major shifts in the space economy of South Africa nationally (Harrison \& Todes, 2013), although the extent to which this is occurring at an intra-city level is a topic that requires further investigation.

\subsection{Access, mobility and the co-benefits}

Access and mobility are concepts that are familiar to the majority of urban residents and part of their daily lives. However, urban inhabitants are unaware of the many co-benefits associated with improved access and mobility. These co-benefits are best identified as "spatial mobility (allocative efficiency), spatial accessibility (distributional equity) and sustainable spatial development" (Himanen, Nijkamp \& Padjen, 1992: 8 ). This is particularly relevant in South African cities, due to the historical placement of non-White residents in peripheral and less desirable parts of the city with poor access to other parts of the city.
There may also be environmental co-benefits to improved access and mobility (UN-Habitat, 2004).

With the rapid urbanisation of South African cities and the current urban morphology, questions as to how this urbanisation, which maximises the poor's access to the urban advantage, can occur, need to be addressed. The predominant public transport mode used in South African cities is the 16-seater minibus taxi, which is not a subsidised, formal form of public transport. Nationally, the minibus taxi carries approximately $65 \%$ of the commuter trips (approximately 14 million trips per day nationwide) (Walters, 2013). In urban areas, this figure varies, although it generally remains the most popular mode of transport, particularly with lowincome earners (Walters, 2013). The introduction of new Bus-Rapid Transit systems in many of South Africa's cities has not necessarily improved access in these cities for the urban poor, as they are generally more expensive than other public transport modes and operate on routes that can pay for the service they provide (Harrison \& Todes, 2013). The Gautrain, Africa's first high-speed rail, is another example of a poor investment in public transport, as it prioritizes the transport of the wealthy passengers, thus promoting further segregation.

The limitation of mobility within a city was a tool used by the apartheid government to constrain social and economic mobility of non-White population groups.

Nowadays, these constraints are still in place in the form of distance to employment opportunities, price of transport, lack of adequate and well-maintained transport infrastructure, and the perceived lack of safety of the available transport options (Harrison \& Todes, 2013). Over $50 \%$ of South African urban households spend more than $20 \%$ of their monthly household income on transport-related costs (Kane, 2006), as well as approximately 80 minutes a day commuting (Kerr, 2015). The time and money spent away from 
economic activity and/or education and/or family responsibilities reduces socio-economic movement (Turok \& Watson 2001; Venter, Biermann \& Van Ryneveld, 2004).

\section{THE ECONOMIC IMPACTS OF URBAN SPRAWL}

There has been a significant amount of research by academia and research think tanks into the economic impact of urban sprawl. Historically, the literature on the economic impact of urban sprawl was generally concerned with the impact of development on the governmental entities' fiscus, associated with the development, particularly local government, and the consequent impact on local government revenue and expenditure (see Mix \& Hurley, 2008). Recently, however, there has been a move towards a more holistic view of economic impact, namely the financial impact on all the role players in development, including businesses, governmental actors, and the inhabitants of the development. The term 'fiscal impact', however, is mainly reserved for the economic impact on government entities only.

These holistic economic effects of urban sprawl extend beyond the fiscal impacts to the inhabitants of both the sprawled area and other urban inhabitants who are affected by externalities related to this sprawled area. As a rule, case studies or more sophisticated planning tools calculate the more holistic economic impacts of urban sprawl. However, the capacity and, in general, the willingness to do these assessments is low.

A study conducted in 2015 by Graham, Spiropoulos and Van Gass found that no metropolitan municipality in South Africa had a tool or method to calculate the holistic economic impact of urban developments in their cities.

The factors that influence the fiscal and financial impact of a development tend to be its location, size, density, building typography, access to infrastructure, and design. A residential development located far from employment opportunities, or one that does not have a mix of residential and commercial land uses also tends to be fiscally nonbeneficial (Mix \& Hurley, 2008). The case studies below elaborate on these factors in more detail.

\subsection{The nature of financial costs in South Africa}

Governmental and non-governmental actors in the urban development process incur two different types of financial costs, namely capital costs and operating costs (Graham, Gull, Southworth \& Loubser, 2013). Capital costs are once-off payments for the initial provision of infrastructure - for example, constructing a waste water treatment plant, installing new capacity into an electrical distribution system, or purchasing vehicles for a new public transport system, and so on). Operating costs are incurred as part of the operation and routine maintenance of infrastructure - for example, pumping water and sewage, fixing burst pipes, the costs of operating a public transport system, and so on). The differentiation between these types of costs is important, as the source of these funds differs. Capital financing for the expansion of infrastructure for low-income households in South Africa is predominantly financed by the national government. The operating costs of infrastructure for these households is mainly subsidised by the national government in line with the legislation on the provision of Free Basic Services. The recent devolution of certain financing requirements for public transport to authorised local governments has shifted the burden of subsidisation to these local governments. This has further justified the need for holistic impact studies of proposed developments (Graham et al., 2013).

The timing of both capital costs and operating costs is also important, as decisions within local governments are often made after considering a funding cycle (generally 3 years) or a political cycle (5 years). Due to these factors and high inflation rates (approximately 5\%-6\%), the longterm impacts of the costs are often not considered. Using discounted Net Present Value (NPV) is a way of presenting all costs in the current monetary values. This is important when considering the urban sprawl versus the compact city debate. The most common theory is that compact cities have a higher upfront capital cost and a cheaper operating cost; sprawled cities have a lower upfront cost and a higher operating cost (O'Toole, 1996; Rode \& Floater, 2014). Using NPV can show the differences between these two scenarios in a way that removes the effects of the timings of the costs.

Another important consideration needs to be made as to where the burden of payment does and should lie (both morally and legislatively). For capital expenditure, according to Section 49 of the Spatial Planning and Land Use Management Act, a developer is responsible for the provision and installation of 'internal infrastructure', and the municipality is responsible for the provision of 'external infrastructure', with some or all of the costs being recovered from the developer. These terms are ambiguous, as is their relation to other common terms such as 'bulk infrastructure', 'connector infrastructure', or 'link infrastructure' (Graham \& Berrisford, 2015). The funding of the 'external infrastructure' may come from various sources, primarily national government transfers, Capital Replacement Reserves (municipal own funding), loans and Development Charges (DCs). South Africa's National Treasury has issued a Draft Policy Framework for Municipal Development Charges setting out draft policies for the application of charges to private developers. These policies are based on the principles of equity, fairness, predictability, spatial and economic neutrality, administrative ease, and uniformity (National Treasury, 2011). Theoretically, the South African intergovernmental fiscal framework is designed such that the national government's capital transfers to municipalities are sufficient to cover the costs of 'external infrastructure' for low-income households. 
Municipalities should utilise other sources (including DCs) to cover 'external infrastructure' for non-poor households and non-residential land uses. For operating expenditure, the national government provides funds to cover the operating costs for the provision of free basic services to low-income and/or indigent residents, while the operating expenditure for businesses and middle- and high-income households should be covered by municipal tariffs. In nearly all cases, tariffs are designed to cover the costs of providing the service for the municipality as a whole. They thus have intricate cross-subsidisation schemes between different customer types, income groups, or geographic areas.

\subsection{Case studies}

The following case studies are a compilation of studies from academia and consultants working on behalf of the government. The first study investigates the impact of suburban sprawl in North American cities. The remaining studies are done in South African cities, with the focus on the fiscal impact of urban sprawl and the impact of urban sprawl on houses in poorly located areas.

\subsubsection{Economic impact of urban sprawl in the United States of America}

The most comprehensive assessment of the costs of urban sprawl in the United States of America has concluded that urban sprawl costs approximately USD 400 billion in external costs, and USD 625 billion in internal costs annually. The external costs accrue to nonresidents of the sprawled areas in the form of traffic congestion, pollution, parking costs, accident costs, and so on. The internal costs accrue to those living in the sprawled areas in the form of increased health costs, due to less walking and more pollution, vehicle costs, vehicle operation, and increased travel time. The report indicates that there are also benefits of urban sprawl, mainly concerning quality of life, due to the increase in space that can be purchased, but these will only accrue to the sprawled community themselves (Litman, 2015). The report also states that the results are "transferrable to developing countries"

(Litman, 2015: 20). However, due to the differences in the nature of urban sprawl between cities in the Global North and the Global South (see Section 3.1), this transference of results is likely to be inaccurate.

\subsubsection{Relationship between density, proximity to the central business district and cost of engineering services in Pretoria, South Africa}

In 2000, Biermann conducted a study in the metropolitan area of Greater Pretoria (now the City of Tshwane Metropolitan Municipality), with the aim of investigating whether the government's promotion of densification and compaction will decrease the capital cost of providing some public services (water, sanitation and electricity), due to economies of scale. The study applied a Bulk Infrastructure Potential Cost Model (BIPCM).

The BIPCM was created to help planners calculate the capital costs of infrastructure associated with a development. The BIPCM is a threshold analysis tool, the theory of which arises from Malisz (1970) and Kozlowski (1971). It can also be used to contrast different development densities on the same site against one another (Biermann, Van Renssen \& Fortuin, 1998). The model calculates the additional bulk infrastructure required to cater for increased demand for water, sanitation and electricity, due to increased population, while considering current capacity. The model then calculates the investment required to fulfil the increased demand. It also takes into account geotechnical, land-use and environmental factors to enhance the predictions of capital costs. The outputs of the model are cost surfaces that can inform planning decisions (Biermann, 2000).

The model found that the capital costs of providing bulk infrastructure per capita do not simply decrease in denser and/or centrally located areas, due to the "unique interrelationships between infrastructure thresholds, capacities, location and density over time and space" (Biermann, 2000: 295). In South Africa, these interrelationships are defined by historically distorted patterns of infrastructure investment, due to apartheid-era relocations, development patterns that have not proceeded according to prediction and legislation, and the specific locational differences in environmental and land-use conditions that result in differential infrastructural development costs. In the case of the City of Tshwane Metropolitan Municipality, Biermann concluded that there is no linear relationship between density, the distance to city centre, and capital costs of infrastructure. It was found that total capital costs increase with increasing density for all services; however, for water and sanitation, they will decrease on a per capita basis until a point where they begin to increase. Electricity capital costs increase on a per capita basis for increasing density. The study also concluded that topographical factors (particularly steep slopes and shallow bedrock) increase the costs of water and sanitation infrastructure provision drastically. It thus concluded that site-specific factors (mainly spare capacity and environmental factors) make the transference of any finding from this or any other study regarding the capital costs for water, sanitation and electricity for differing density development, inappropriate (Biermann, 2000).

Biermann's findings that the capital costs for water, electricity and sanitation in a more compact scenario cannot be transferred to another city are convincing. However, this is only part of the economics of the compact versus sprawled city argument. One of the major economic arguments is that it is short-sighted to consider only the capital costs, although Biermann acknowledged that the operating costs would play a role in the financial sustainability of the urban form (particularly those of transport). 


\subsubsection{The impact of urban sprawl on a hypothetical South African city}

In 2011, the Financial and Fiscal Commission of South Africa commissioned Palmer, Berrisford and Brown-Luthango to test the hypothesis that urban sprawl in South African cities leads to a less 'efficient' city. These calculations were done by creating a Microsoft Excel tool that calculated the capital and operating costs of transport, municipal infrastructure (water supply, sanitation, electricity, solid waste disposal, and roads), land and housing over a 10-year period. The costs of social services such as schools and hospitals were not included. The costs and revenues were allocated between three actors: the State, the City, and the private sector (consisting of households and businesses). Households have been divided into two income groupings. This is important as the tariff and subsidy structures vary at different income levels, as depicted in Figure 1.

The City Efficiency Costing Model was developed and applied to two hypothetical cities, a sprawled city and a compact city. These hypothetical cities were based on the similar characteristics that South African cities share: "low cost housing on the periphery, informal settlements on small parcels around the city, racially segregated communities... [with] spatial growth that is informed by Apartheid planning policies and housing subsidy structure" (Palmer et al., 2011: 12).

The demographic and economic growth rates of the two hypothetical cities were kept constant, so that the only difference in costs between the two scenarios was due to the urban form.

The study considered the costs of new infrastructure, the costs of the renewal of existing infrastructure, and the operating costs of municipal services for the two scenarios and concluded that, over a 10-year period, a sprawled city is more expensive than a compact city. The difference for the capital costs between the two scenarios is small, with the sprawled scenario being $2.1 \%$ more expensive. This is due to larger pieces of land being purchased, the increased length of infrastructure required, and longer public transport networks. The per capita utilisation of the installed infrastructure is also less, due to decreased density. The most poignant example of increased expenditure is the capital investment required for public transport infrastructure. There will be less trips on public transport infrastructure in a sprawled scenario. Therefore, per trip, the investment is significantly more expensive. ${ }^{2}$ The operating costs of the compact city are $7 \%$ less than those of the sprawled city. This amounts to approximately

2 There is an argument to be made that, due to the increased cost of the public transport function, there may be no public transport provided in financially unviable areas and that, therefore, this should not be considered an economic cost.

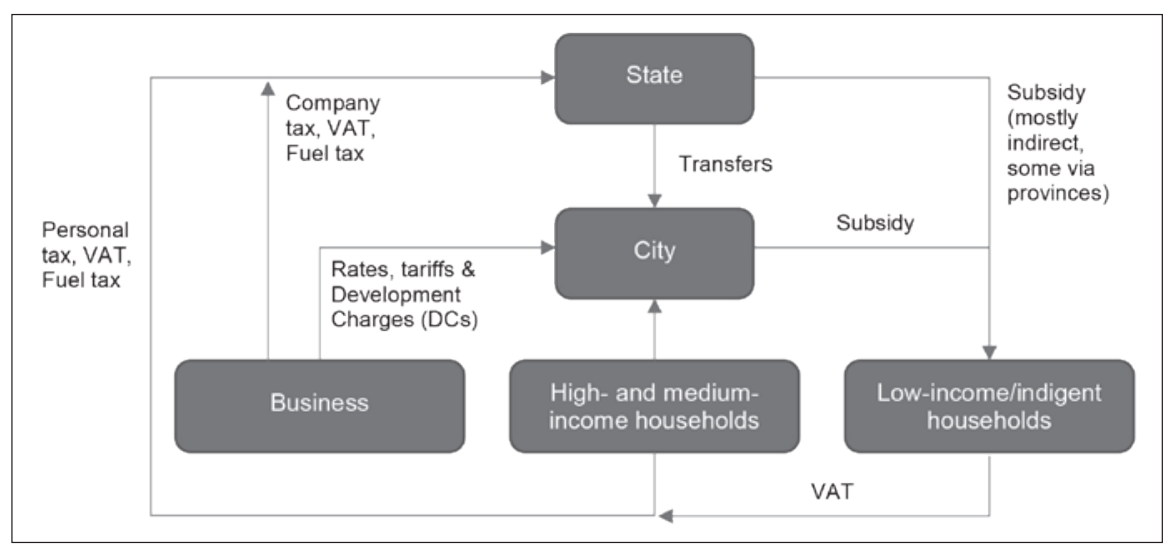

Figure 1: Framework for fiscal flows in South African cities

Source: $\quad$ Adapted from Palmer, Berrisford \& Brown-Luthango, 2011: 14
R6.8 billion per annum over 10 years. Households of all incomes would pay less in the compact scenario. When comparing the total cost of the two scenarios to the business-asusual scenario over a 10-year period, low-income households' expenditure will increase by $14 \%$ monthly in the sprawled scenario, whilst in the compact scenario their monthly household expenditure will decrease by $10 \%$. These differences are mainly due to the costs of transport.

The report states that, if the findings are extrapolated to the six largest cities in South Africa, the difference between the two scenarios would be approximately $1.4 \%$ of GDP by year 10 , and this cost difference would increase with time. The report also investigated the environmental impacts of urban sprawl and found the sprawled scenario to be significantly worse, primarily from increased carbon emissions arising from increased travel distance and private car use. Policy recommendations from the report include prioritising public transport for the urban poor, urban sprawl limitation measures, creation of welllocated housing for the urban poor, and incentives for private developers to shift to more compact forms of development (Palmer et al., 2011).

\subsubsection{The location of low-income housing in South Africa: A sustainable livelihoods framework approach}

In 2004, Venter et al. carried out an empirical investigation in eight areas in eThekwini and Johannesburg to assess the actual costs and benefits of the location of housing in the lives of urban residents. The considered costs included costs accrued by governmental and non-governmental actors as well as the capital and operating costs of all infrastructure. The benefits of the location of the housing were also investigated, using the sustainable livelihoods framework. ${ }^{3}$

The case studies found that the cost of land varied between and within

3 For a description of the sustainable livelihood framework, see Carney (1998). 
centrally located and peripherally located areas. In some instances, well-located areas were more expensive, while in others the peripherally located land was more expensive. The cost of providing 'bulk infrastructure' (water, waste water, roads, and electricity) to new settlements varies according to the excess capacity in the system and the need for further investments to upgrade the infrastructure. In the case studies, the marginal cost of the provision of water varied between R20 000 per household to almost zero where excess capacity was available. The costs of the provision of social facilities to areas further from urban centres appear to be largely insensitive to the location of the site (Venter et al., 2004).

The costs of transport are, as is, intuitive. Sites located further from the central business district (CBD), where the highest concentration of employment in the city usually exists, incur higher transport costs than those located closer to the CBD. However, several important findings arise from the transport analysis. In some of the areas of study, the proximity to middle- and upper-income residential areas is more important than proximity to the CBD, due to employment of informal, unskilled labour such as garden maintenance or house cleaning in these areas. Another factor influencing the costs of transport is the size of the entire metropolitan area, rather than location within it, as peripheral locations in a smaller city are closer to the CBD than peripheral locations in a larger urban centre, and hence cheaper to access. Modal choice is also a factor, as formal modes (bus and rail) are subsidised by public funds, whereas informal or private modes (minibus taxi or the use of one's own vehicle) have no access to public subsidies. Therefore, the entire burden of payment lies on the users of the service.

The sustainable livelihoods framework analysis shows that, in general terms, peripheral locations have better access to natural capital, whereas central locations have better access to social and physical (infrastructural) assets. However, in Johannesburg, some of the more peripheral locations may have access to better physical and social assets, yet worse access to natural assets than the centrally located sites.

The findings from the case study sites investigated by Venter et al. (2004) do not support the compact city hypothesis that more central locations necessarily have lower overall costs and offer higher benefits than more peripheral locations. A more nuanced perspective on location, rather than the dichotic 'central' and 'peripheral', is necessary. The location of housing relative to employment and social amenities and how these relative locations are affected over time will need to be researched and understood better for each potential location for low-income housing (Venter et al., 2004).

\subsubsection{Fiscal impact of urban sprawl on Western Cape municipalities, South Africa}

In 2013, Graham et al. conducted a fiscal impact study on the financial sustainability of current growth patterns in cities of the Western Cape, South Africa. The report was commissioned by the Western Cape Government's Department of Environmental Affairs and Development Planning in response to municipalities making planning decisions based on "short-term gains, be they political, economic, or pragmatic" (Graham et al., 2013: 1). The authors used a Microsoft Excel-based tool called the Municipal Services Financial Model to calculate the municipal financial sustainability of seven municipalities based on different urban growth patterns over a 10-year period. In addition to the municipal financial sustainability, non-financial factors such as the impact of urban growth on social, cultural, scenic and the environment were considered.

The research found that there is a $17 \%$ decrease in capital expenditure and a $20 \%$ reduction in operating expenditure over a 10-year period in the more compact scenario. It also found that the negative financial impact of urban sprawl is more significant in larger towns and has a smaller impact in smaller towns. This research is valuable for municipalities in South Africa, as they are facing significant constraints on their budgets, particularly on the operating account, whereby increases in the expenses incurred in the provision of services are not covered by tariffs, due to the politically contested nature of tariff increases. As an example, municipal tariff increases of $4 \%$ above inflation (approximately 10\% in nominal terms), in the sprawled scenario, would be required in order to attain financial viability of the operating account. This tariff increase is unlikely, as increases above inflation are uncommon, except for electricity in some circumstances (Graham et al., 2015).

Due to the incomplete devolution of functions to South African local government, the public transport function in many smaller municipalities is not a responsibility of local government. This is important, as transport has the potential to impact on spatial growth patterns (see Cervero, 2001). The case study found that low-income households in many municipalities in the Western Cape are unable to afford transport, and are, therefore, 'trapped' where they live, and consequently unable to travel to places of employment, healthcare, schooling and other urban amenities. For example, the current spatial growth patterns would result in low-income households in the City of Cape Town Metropolitan Municipality spending approximately $18 \%$ more on transport than in a more compact scenario. In smaller municipalities, the financial impact is less, although the impact of transport emissions is higher per trip, due to the prevalence of road-based public transport in smaller urban centres. On aggregate, carbon emissions due to transport are $33 \%$ higher in the province in the sprawled scenario.

In smaller towns, the impact of the loss of biodiversity, cultural, scenic and heritage landscapes was more 
significant than in the larger cities. It was found that the urban edge in the majority of municipalities is being adjusted to accommodate new housing projects located on the urban periphery, regardless of the town's size. Proximity and accessibility of these new developments to the rest of the city are not taken into account. The movement of the urban edge disincentivises infill development, consequently converting agricultural land into mono-functional, generally residential, developments.

In addition, the integration of income groups is not prioritised, as the predominant middle- to high-income private residential development is a socially segregated, gated community (Ramoroka \& Tsheola, 2014; Graham et al., 2015).

\subsubsection{The cost of land versus the cost of public transport - Cape Town, South Africa}

This report was commissioned by the City of Cape Town and performed by PDG. The study investigated whether the higher capital cost of low-income housing in well-located areas would be less than the cost of providing transport services to an equivalent site in a peripherally located area over a 20 -year period. The costs that were considered are the costs of land, the capital and operating costs of municipal services, and transport to employment and urban amenities. Two housing developments on different sites, namely Greenville and Heideveld, were selected as case studies (see Figure 2). Greenville is a large, outlying, subsidised housing development with low levels of accessibility to the CBD and low land values. Heideveld is a medium-sized, subsidised housing development with a moderate level of accessibility and moderate land values (Kaplan \& Graham, 2017). A Microsoft Excel tool was used to calculate the long-term, holistic economic impact of the two developments.

The two sites have different numbers of housing and different housing typologies built on them.

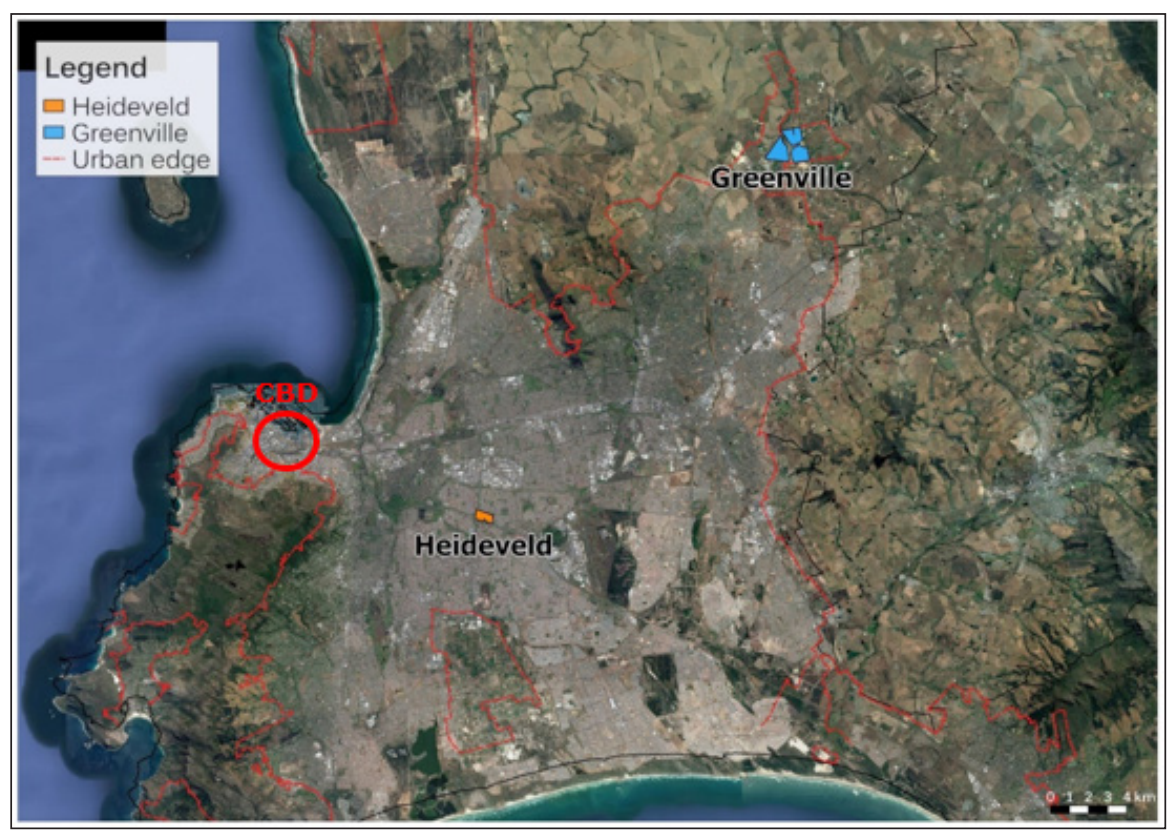

Figure 2: Greenville (peripheral) and Heideveld (well-located) case study locations Source: Kaplan \& Graham, 2017

Table 2: $\quad$ Public transport submodal splits in base year and year 20

\begin{tabular}{|l|c|c|c|c|c|c|c|c|c|c|}
\hline & \multicolumn{5}{|c|}{ Greenville } & \multicolumn{5}{c|}{ Heideveld } \\
\hline & Bus & Rail & IRT $^{5}$ & NMT $^{6}$ & MBT $^{7}$ & Bus & Rail & IRT & NMT & MBT \\
\hline Base year & $14 \%$ & $34 \%$ & $3 \%$ & $7 \%$ & $43 \%$ & $15 \%$ & $13 \%$ & $30 \%$ & $20 \%$ & $22 \%$ \\
\hline Year 20 & $29 \%$ & $21 \%$ & $32 \%$ & $11 \%$ & $7 \%$ & $28 \%$ & $16 \%$ & $44 \%$ & $5 \%$ & $7 \%$ \\
\hline
\end{tabular}

Source: Kaplan \& Graham, 2017

The different housing typologies play a big role in the cost of housing. ${ }^{4}$ In order for the two locations to be compared against each other on equal terms, the authors derived an equation to ensure that the results of the modelling represented the difference due to the location only.

The study showed that transport was the main cost differential between different sites. The sites have different transport characteristics, with varying modal splits between the sites, in the base year and in year 20. These were calculated using a transport model (see Table 2).

In addition to having different modal splits, the sites had different trip distances, due to their proximity to employment and urban amenities (see Table 3).

Table 3: Trip distance in base year and year 20

\begin{tabular}{|l|c|c|}
\hline & Greenville & Heideveld \\
\hline Base year & $20.4 \mathrm{~km}$ & $9.9 \mathrm{~km}$ \\
\hline Year 20 & $19.03 \mathrm{~km}$ & $11.6 \mathrm{~km}$ \\
\hline
\end{tabular}

Source: Kaplan \& Graham, 2017

The results of the study show that the NPV of the long-term cost of the development in the central location is less than that in a more peripheral location. The NPV of the capital costs of the more centrally located site is R12 million higher than the peripheral site. However, this is more than offset by the NPV of the operating costs, which are R37 million cheaper for the centrally located site. This difference in the operating costs is predominantly due to the difference in transport expenditure. When considering how the costs are apportioned between the different governmental and non-governmental actors over a 20-year period, the better located site is marginally cheaper to both the municipality and

4 An investigation into the differential capital costs of housing typologies in Mamelodi, South Africa showed that a basic walk-up unit of $60 \mathrm{~m}^{2}$ is almost three times as expensive as a peripheral RDP house of a plot size of $250 \mathrm{~m}^{2}$ and a house of $30 \mathrm{~m}^{2}$ on it (Schoonraad, 2000).

5 Integrated Rapid Transit.

6 Non-motorised transport.

7 Minibus taxi. 
the State. This is mainly due to less 'connector infrastructure' required for construction of low-income housing within the existing infrastructure footprint. The well-located site is significantly more beneficial to households because of savings on transport costs and the additional capital asset value, due to the higher value of the land, which is intrinsically linked to the location of the site.

Based on these findings, the report states a number of policy recommendations: the norms and standards contained in the South African National Standard's Housing Code should be revisited, as they currently incentivise the construction of impoverishing households; rationalise the public transport institutional arrangements; consolidate grant funding, and evaluate long-term costs and benefits when making planning decisions.

\subsubsection{Medium-term infrastructure investment framework, Cape Town}

The City of Cape Town Metropolitan Municipality has embarked on a comprehensive assessment of three different city-wide development trajectories with varying levels of Transit-Oriented Development rankings. The results are currently embargoed. However, the preliminary analysis indicates that a more compact city requires a greater outlay of capital, which is not necessarily outweighed by the savings made to households, due to decreased expenditure on shorter transport routes. These results are specific to the City of Cape Town and are likely not transferable to other cities, as the results are heavily reliant on local, contextual factors and the specific arrangements of developments within the different development trajectories.

\subsubsection{Case study summary}

The case studies presented in this article show that numerous factors influence the cost of the urban form. These are summarised in Table 4. The results are analysed in Section 6.

Table 4: $\quad$ Case study findings contrasting the cost of sprawled and compact urban forms and the factors that influence this cost

\begin{tabular}{|c|c|c|c|c|}
\hline & Capital cost & Operating cost & Factors impacting on cost & Primary findings \\
\hline Litman, 2015 & \multicolumn{2}{|c|}{$\begin{array}{l}\text { The overall cost of compact urban form } \\
\text { is lower than a sprawled urban form (the } \\
\text { breakdown of capital and operating costs } \\
\text { was not given) }\end{array}$} & $\begin{array}{l}\text { - Health costs } \\
\text { - Cost of vehicle accidents } \\
\text { - Congestion } \\
\text { - Pollution } \\
\text { - Parking costs } \\
\text { - Travel time }\end{array}$ & $\begin{array}{l}\text { In the context of the Global North, sprawled cities cost the } \\
\text { economy in excess of USD } 1 \text { trillion annually and should thus } \\
\text { be discouraged }\end{array}$ \\
\hline $\begin{array}{l}\text { Biermann, } \\
2000\end{array}$ & $\begin{array}{l}\text { Does not conclude } \\
\text { whether sprawled } \\
\text { urban form or } \\
\text { compact urban } \\
\text { form is cheaper }\end{array}$ & Not considered & $\begin{array}{l}\text { - Infrastructure capacity } \\
\text { - Topography } \\
\text { - Density } \\
\text { - Location }\end{array}$ & $\begin{array}{l}\text { There are interrelationships between infrastructure thresholds, } \\
\text { capacities, location and density over time and space }\end{array}$ \\
\hline $\begin{array}{l}\text { Palmer et al., } \\
2011\end{array}$ & $\begin{array}{l}\text { Cheaper in } \\
\text { compact urban } \\
\text { form }\end{array}$ & $\begin{array}{l}\text { Cheaper in } \\
\text { compact urban } \\
\text { form }\end{array}$ & $\begin{array}{l}\text { - Extent of infrastructure network } \\
\text { - Cost of public transport }\end{array}$ & $\begin{array}{l}\text { - Prioritise the provision of public transport, particularly for } \\
\text { urban poor } \\
\text { - Limit urban sprawl through regulatory measures } \\
\text { - Provide well-located, low-income housing }\end{array}$ \\
\hline $\begin{array}{l}\text { Venter et al., } \\
2004\end{array}$ & $\begin{array}{l}\text { Does not conclude } \\
\text { whether sprawled } \\
\text { urban form or } \\
\text { compact urban } \\
\text { form is cheaper }\end{array}$ & $\begin{array}{l}\text { Does not conclude } \\
\text { whether sprawled } \\
\text { urban form or } \\
\text { compact scenario } \\
\text { is urban form }\end{array}$ & $\begin{array}{l}\text { - Infrastructure capacity } \\
\text { - Cost of public transport }\end{array}$ & $\begin{array}{l}\text { - There is a false dichotomy between urban sprawl and } \\
\text { compact cities, need a more nuanced understanding of poorly } \\
\text { and well located } \\
\text { - In smaller cities, the impacts of urban sprawl are less } \\
\text { - Public transport should be provided to the urban poor } \\
\text { - The accessibility to other livelihood amenities (natural, social } \\
\text { and physical capital) is not related to the sprawled or compact } \\
\text { city }\end{array}$ \\
\hline $\begin{array}{l}\text { Graham et } \\
\text { al., } 2013\end{array}$ & $\begin{array}{l}\text { Cheaper in } \\
\text { compact urban } \\
\text { form }\end{array}$ & $\begin{array}{l}\text { Cheaper in } \\
\text { compact urban } \\
\text { form }\end{array}$ & $\begin{array}{l}\text { - Extent of infrastructure network } \\
\text { - Cost of public transport }\end{array}$ & $\begin{array}{l}\text { - In smaller cities, the impacts of urban sprawl are less } \\
\text { - The current spatial patterns in municipalities are not } \\
\text { financially sustainable } \\
\text { - Compact settlements save people time and money } \\
\text { - Long-term financial, social and environmental costs need to } \\
\text { be considered in the municipal planning and decision-making } \\
\text { cycles }\end{array}$ \\
\hline $\begin{array}{l}\text { City of Cape } \\
\text { Town, } 2017\end{array}$ & $\begin{array}{l}\text { Cheaper in } \\
\text { sprawled urban } \\
\text { form }\end{array}$ & $\begin{array}{l}\text { Does not conclude } \\
\text { whether sprawled } \\
\text { urban form or } \\
\text { compact urban } \\
\text { form is cheaper }\end{array}$ & $\begin{array}{l}\text { - Cost of public and private } \\
\text { transport } \\
\text { - Extent of infrastructure network } \\
\text { - Infrastructure capacity }\end{array}$ & $\begin{array}{l}\text { - There is limited difference in the financial and fiscal efficiency } \\
\text { of sprawled or compact cities, as the exact make-up of land } \\
\text { parcels is more important than whether the city is compact or } \\
\text { sprawled } \\
\text { - Benefits beyond financial and fiscal efficiency, when } \\
\text { considering urban morphology, need to be considered in the } \\
\text { decision-making process }\end{array}$ \\
\hline
\end{tabular}




\section{HOUSING AS URBANISM: A NEW POLICY DIRECTION?}

In South Africa, cities are sprawling, despite government's current attempts at controlling it. Urban sprawl in South Africa has been driven by government's RDP housing scheme, the dynamics of the land market, private sector speculation, poorly enforced planning legislation and planning legislation that does not adequately consider informal logics. Due to municipal planning cycles and the pervasive financial logic that informs municipal decision-making in South Africa, low-income housing, which conforms to principles of urbanism, has mainly been viewed as unnecessary and not worth the additional bureaucratic processes and capital outlay to develop. This is particularly relevant when considering the scale of the housing backlog in South Africa and the limited capital funding available for low-income housing development. The fiscal framework and Housing Code have also, until recently, dis-incentivised municipalities to construct urbanist housing, with the payment of the land for housing, the housing itself and public transport coming from national government, as well as restrictions on the size of the units that could be constructed.

The case studies presented in this article investigated the economic impact of urban sprawl, both at a city-wide level and at a development level. However, the findings are not consistent, as indicated in Table 4. Analyses of the impact of urban sprawl on the municipalities' finances show that capital costs for networked infrastructure (water, sanitation and electricity) can be cheaper or more expensive in a compact or sprawled city. These costs are impacted by the excess capacity present in the system, the land-use mix in a city, topographical factors such as slope and altitude, distances between nodes in the city, density, and land-use mix variation over time and in space.
The case studies, which took into account the capital and operating costs of transport, generally showed that areas further from centres of employment are more expensive than the centrally located ones, although this was dependant on the mode of transport available. A study on the longer term economic impact of sprawled cities found that the cheaper transport costs were outweighed by the increased cost of land and buildings. The cost of transport is, intuitively, a major factor in the sprawled versus compact city debate. However, a dichotomous 'central' and 'peripheral' conception of location should be replaced by a more nuanced 'well located' and 'poorly located' conception of space (Venter et al., 2004).

The factors influencing the sprawled versus the compact city debate are too numerous and too complex for conclusive findings to be made generically. In order to make decisions that can impact less negatively on both the municipal fiscus and the monthly expenditure of the inhabitants of the residential developments, municipalities should include an analysis into the long-term financial impact of a development in the planning approval process. Such an analysis is difficult to perform, as there is a trade-off between a simple tool that can give broad, indicative results, and a tool that is complex, and thus time consuming, but can provide accurate results (Graham, 2015). Tools need to have an in-depth understanding of the relationships between land values in space, the mix and costs of buildings, land uses and urban services, the relative cost of transport, as well as excess capacities in the systems. These components will generally be the most significant cost items, and their characteristics and interrelationships must be understood at a sitespecific level. When social or low-income housing is being considered, the long-term costs to the inhabitants of the house should be an important consideration for the municipality, as municipalities have a developmental mandate.
Considerations should include economic, social, environment and political factors. Once these are understood, a targeted approach to densification and Transit Oriented Development can achieve the objectives of 'housing as urbanism', and consequently, a more efficient city. A more nuanced understanding of the true fiscal and financial costs of developments, which accrue due to their location in space, can lead to better decision-making regarding the development contributions that developers should make to municipalities, in order to develop in a particular area.

When considering 'housing as urbanism', the concept of space becomes important, as nodes of urban amenities, employment and residence become more interspersed throughout the city, rather than in a central, single area. 'Housing as urbanism' could allow planners to locate residential areas, social facilities, urban amenities and areas of employment close to one another, as it considers the holistic value of a house to its residents. This would, in turn, reduce trip distances and potentially create a more efficient urban area. 'Housing as urbanism' addresses the relative location of housing in space. However, attention also needs to be paid to the design of the physical housing unit itself and the combined public space with which the residents interact. Without these two factors considered, it is unlikely that the resident will enjoy the social, political, economic freedoms and improved quality of life that can accrue from urban dwelling.

This study has shown that the principles of 'housing as urbanism' are likely to be a financially sound decision, and that there are also many other social and environmental co-benefits that would accrue if the concept were adopted. Decisions taken, which consider the principles of 'housing as urbanism', can help create a more efficient urban form, freeing up resources for both urban residents and public sector organisations alike. 


\section{ACKNOWLEDGEMENT}

The author would like to credit Mr. Jorge Fiori from the Developement Planning Unit at University College London, who supervised this research.

\section{REFERENCES}

ALKIRE, S., FOSTER, J., SETH, S., SANTOS, E.M., ROCHE, J.M. \& BALLON, P. 2015. Multidimensional poverty measurement and analysis. Oxford: Oxford University Press. https://doi.org/10.1093/acprof:o so/9780199689491.001.0001

ALTSHULER, A. \& GOMEZ-IBANEZ, J. 1993. Regulation for revenue: The political economy of land use exactions. Washington, D.C.: Brookings Institution.

ANGEL, S., PARENT, J., CIVCO, D. \& BLEI, A. 2011. Making room for a planet of cities. Cambridge: Lincoln Institute of Land Policy.

AUDIRAC, I., SHERMYEN, A. \&

SMITH, M. 1990. Ideal urban form and visions of the good life. Florida's growth management dilemma. Journal of the American Planning Association, 56(4), pp. 470-482. https://doi. org/10.1080/01944369008975450

BEKELE, H. 2005. Urbanisation and urban sprawl. Stockholm: Master of Science thesis No. 294. Kungliga Tekniska Högskolan.

BERTAUD, A. 2009. Note on spatial issues in South Africa. [online]. Available at: <http://alainbertaud. com/wp-content/uploads/2013/06/ AB_Note-on-South-Africa.pdf> [Accessed: 7 July 2017].

BHATTA, B., SARASWATI, S. \& BANDYOPADHYAY, D. 2010. Urban sprawl measurement from remote sensing data. Applied Geography, 30(4), pp. 731-740. https://doi. org/10.1016/j.apgeog.2010.02.002

BIERMANN, S. 2000. Bulk engineering services: Costs and densities. In: Jenks, M. \& Burgess, R. (Eds). Compact cities: Sustainable urban forms for developing countries. London: Spon Press, pp. 295-310.

BIERMANN, S., VAN RENSSEN, C. \& FORTUIN, O. 1998. Bulk infrastructure cost model: Integrating engineering services into the strategic planning process. East London: SAICE.
BIRCH, J. 2015. Housing and poverty. York: Joseph Rowntree Foundation.

BOLAY, J.C. 2006. Slums and urban development: Questions on society and globalization. The European Journal of Development Research, 18(2), pp. 284-298. https://doi. org/10.1080/09578810600709492

BROWN, D. 2017. Challenging the conceptual boundaries of the compact city paradigm in sub-Saharan Africa: Towards Southern alternatives. London: DPU Working Paper No. 187.

BURCHELL, R. \& LISTOKIN, D. 1978. The fiscal impact handbook: Estimating local costs and revenues of land development. New Brunswick: Transaction Publishers.

CARNEY, D. 1998. Sustainable rural livelihoods: What contribution can we make? London: Department for International Development.

CERVERO, R. 2001. Integration of urban transport and urban planning. In: Freire, M. \& Stren, R. (Eds). The challenge of urban government policies and practices. Washington, D.C.: The World Bank, pp. 407-427.

COCIÑA, C. 2017. Housing as urbanism: The role of housing policies in reducing urban inequalities. London: The Bartlett Development Planning Unit, University College London.

CONGRESS OF THE NEW URBANISM. n.d. The Charter of the New Urbanism. [Online] Available at: <https://www.cnu.org/ who-we-are/charter-new-urbanism> [Accessed: 3 August 2016].

DEWAR, D. 2000. The relevance of the compact city approach: The management of urban growth in South African cities. In: Jenks, M. \& Burgess, R. (Eds). Compact cities: Sustainable urban forms for developing countries. London: Spon Press, pp. 208-218.

DIELEMAN, F. \& WEGENER, M. 2004. Compact city and urban sprawl. Built Environment, 30(4), pp. 308-323. https://doi.org/10.2148/ benv.30.4.308.57151

DUANY, A., PLATER-ZYBERK, E. \& SPECK, J. 2000. Suburban nation: The rise of sprawl and the decline of the American Dream. New York, NY: North Point Press.
DUNN, E. 1983. The development of the US urban system. Washington, DC: Resources for the Future.

DU PLESSIS, D. \& BOONZAAIER, I. 2015. The evolving spatial structure of South African cities: A reflection on the influence of spatial planning policies. International Planning Studies, 20(1-2), pp. 87-111. https://doi.org/10.1080/1356 3475.2014.942505

FERRARI, E. 2015. The social value of housing in straitened times: The view from England. Housing Studies, 30(4), pp. 514-534. https://doi.org/10.1080/02 673037.2013.873117

FIORI, J. 2013. Informal city: Design as political engagement. In: Verebes, T. (Ed.). Masterplanning the adaptive city: Computational urbanism in the twentyfirst century. London: Routledge, pp. $40-47$

FIORI, J. \& BRANDÃO, Z. 2010. Spatial strategies and urban social policy: Urbanism and poverty reduction in the favelas of Rio de Janeiro. In: Hernández, F., Kellett, P. \& Allen, L.K. (Eds). Rethinking the informal city. Critical perspectives from Latin America. New York: Berghahn Books, pp. 181-205.

GALSTER, G., HANSON, R., RATCLIFFE, M.R., WOLMAN, H., COLEMAN, S. \& FREIHAGE, J. 2001. Wrestling sprawl to the ground: Defining and measuring an elusive concept. Housing Policy Debate, 12(4), pp. 681-717. https://doi.org/10.1080/10 511482.2001.9521426

GRAHAM, N. \& BERRISFORD, S. 2015. Development charges in South Africa: Current thinking and areas of contestation. Cape Town: IMESA, pp. 1-13

GRAHAM, N., GULL, K., SOUTHWORTH, B. \& LOUBSER, J. 2013. Municipal financial sustainability of current spatial growth patterns. Cape Town: Western Cape Government: Department of Environmental Affairs and Development Planning.

GRAHAM, N., SPIROPOULOS, J. \& VAN GASS, C. 2015. Assessing the fiscal impact of development. Johannesburg: South African Cities Network.

HARRISON, P. \& TODES, A. 2013. Spatial considerations in the development of urban policy in South Africa: A research paper as input into 
the preparation of the Integrated Urban

Development Framework (IUDF).

Pretoria: Department of Cooperative

Development and Traditional Affairs.

HIMANEN, V., NIJKAMP, P. \& PADJEN, J. 1992. Transport mobility, spatial accessibility and environmental sustainability. Research Memoranda Series, 53, pp. 1-32.

HOGARTH, K. 2015. Leveraging the private sector to enable the delivery of well-located affordable housing in Cape Town. Cape Town: University of Cape Town.

JOHNSON, M. 2001. Environmental impacts of urban sprawl: A survey of the literature and proposed research agenda. Environment and Planning, 33, pp. 717-735. https://doi.org/10.1068/ a3327

KANE, L. 2006. Transport problems associated with poverty in South Africa. Pretoria: s.n.

KAPLAN, J. \& GRAHAM, N. 2017. Medium Term Infrastructure Investment Framework (MTIIF); Cost of land versus cost of public transport. s.l.: Unpublished.

KERR, A. 2015. Tax(i)ng the poor? Commuting costs in South Africa, Cape Town: A Southern Africa Labour and Development Research Unit Working Paper No. 156.

KOZLOWSKI, J. 1971. The place and role of threshold analysis in the model planning process. Ekistics, 192(32), pp. 348-353.

LEICHENKO, R. \& SOLECKI, W. 2005. Exporting the American Dream: The globalization of suburban consumption landscapes. Regional Studies, 39(2), pp. 241-253. https://doi. org/10.1080/003434005200060080

LITMAN, T. 2015. Analysis of public policies that unintentionally encourage and subsidize urban sprawl. Victoria, BC: Victoria Public Transport Institute.

MADDEN, D. \& MARCUSE, P. 2016. In defence of housing: The politics of crisis. London: Verso.

MALISZ, B. 1970. Implications of threshold theory for urban and regional planning. In: Richardson, H.W. (Ed.) Regional economics. London: Palgrave Macmillan, pp. 220-230. https://doi. org/10.1007/978-1-349-15404-3_17

MARTIN, R., MOORE, J. \&

SCHINDLER, S. 2015. The art of inequality: Architecture, housing, and real estate. New York: The Trustees of Columbia University.

McKEE, B. 2003. As suburbs grow, so do waistlines. New York Times, 4 September, p. F00001.

McKINNEY, M. 2002. Urbanization, biodiversity and conservation. BioScience, 52(10), pp. 883-890. https://doi.org/10.1641/00063568(2002)052[0883:UBAC]2.0. $\mathrm{CO} ; 2$

\section{MINISTRY OF COOPERATIVE} GOVERNANCE AND TRADITIONAL AFFAIRS. 2016. Integrated Urban Development Framework. Pretoria: Cooperative Governance and Traditional Affairs.

MIX, T. \& HURLEY, R. 2008. Fiscal impacts of development: Literature review and discussion. Neward, DE: University of Delaware, Institute for Public Administration.

MOSER, C. \& DANI, A. 2008. Assetbased social policy and public action in a polycentric world. In: Moser, C. \& Dani, A. (Eds.). Assets, livelihoods and social policy. Washington, D.C.: The World Bank, pp. 3-42. https://doi. org/10.1596/978-0-8213-6995-1

NAPIER, M. 2007. Making urban land markets work better in South African cities and towns: Arguing the basis for access by the poor. Washington, D.C.: s.n., pp. 1-30.

NATIONAL PLANNING COMMISSION. 2012. Our future-make it work. National Development Plan 2030. Pretoria: s.n.

NATIONAL TREASURY. 2011. Draft policy framework for municipal development charges. Pretoria: Government Press.

NELL, M., GORDON, R. \& BERTOLDI, A. 2004. Workings of township residential property markets: Final report. Johannesburg: FinMark Trust.

ODENDAAL, N. \& McCANN, A. 2016. Spatial planning in the global South: Reflections on the Cape Town Spatial Development Framework. International Development Planning Review, 38(4), pp. 405-423. https://doi.org/10.3828/ idpr.2016.23

O'TOOLE, R. 1996. The vanishing automobile and other urban myths: How smart growth will harm American cities. Spring: The Thoreau Institute.

PALMER, I., BERRISFORD, S. \& BROWN-LUTHANGO, M. 2011. The economic and fiscal costs of inefficient land use patterns in South Africa. Cape Town: Financial and Fiscal Commission.

PALMER, I., PARNELL, S. \& MOODLEY, N. 2017. Building a capable state: Service delivery in post-apartheid South Africa. London: Zed Books.

PIETERSE, E. 2009. Post-apartheid geographies in South Africa: Why are urban divides so persistent? Leuven: Leuven University Press.

PUTNAM, R. 2000. Bowling alone. New York, NY: Simon \& Schuster.

RAMOROKA, T. \& TSHEOLA, J. 2014. Gated communities and the privatization of public spaces in urban South Africa: Democratic social integration or exclusion? Journal of Geography and Regional Planning, 7(4), pp. 58-68. https://doi.org/10.5897/ JGRP2013.0396

RICHARDS, R., O'LEARY, B. \& MUTSONZIWA, K. 2007. Measuring quality of life in informal settlements in South Africa. Social Indicators Research, 81(2), pp. 375-388. https:// doi.org/10.1007/s11205-006-9014-1

RODE, P. \& FLOATER, G. 2014. Accessibility in cities: Transport and urban form. London: LSE Cities.

RSA (REPUBLIC OF SOUTH AFRICA). 1996. Constitution of the Republic of South Africa, Act No. 108 of 1996. Pretoria: Government Printer.

SCHOONRAAD, M. 2000. Cultural and institutional obstacles to compact cities in South Africa. In: Jenks, M. \& Burgess, R. (Eds). Compact cities: Sustainable urban forms for developing countries. London: Spon Press, pp. 219-230.

SKABURSKIS, A. 2006. New urbanism and sprawl: A Toronto case study. Journal of Planning Education and Research, 25(3), pp. 233-248. https:// doi.org/10.1177/0739456X05278985

SOUTH AFRICAN CITIES NETWORK. 2004. The State of the Cities Report. Johannesburg: South African Cities Network.

SOUTH AFRICAN CITIES NETWORK. 2016. The State of the Cities Report. Johannesburg: South African Cities Network.

STATSSA (STATISTICS SOUTH AFRICA). 2012. Census 2011. Pretoria: Statistics South Africa. 
STURM, R. \& COHEN, D. 2004. Suburban sprawl and physical and mental health. Public Health, 118(7), pp. 488-496. https://doi.org/10.1016/j. puhe.2004.02.007

TALEN, E. 2005. New urbanism and American planning: The conflict of cultures. London: Routledge. https:// doi.org/10.4324/9780203799482

TALEN, E. 2006. Connecting new urbanism and American planning: An historical interpretation. Urban Design International, 11, pp. 83-98. https://doi. org/10.1057/palgrave.udi.9000166

THOMAS, D. 2013. The Gautrain project in South Africa: A cautionary tale. Journal of Contemporary African Studies, 31(1), pp. 77-94. https://doi.org /10.1080/02589001.2013.747292

TODES, A. 2003. Housing, integrated urban development and the compact city debate. In: Harrison, P., Huchzermeyer, M. \& Mayekiso, M. (Eds). Confronting fragmentation: Housing and urban development in a democratising society. Cape Town: University of Cape Town Press, pp. 109-121.

TURNER, J. 1976. Housing by people: Towards autonomy in building environments. London: Marion Boyars Publishers Ltd.

TUROK, I. 2001. Persistent polarisation post-apartheid? Progress towards urban integration in Cape Town. Urban Studies, 38(13), pp. 2349-2377. https:// doi.org/10.1080/00420980120094551

TUROK, I. \& BOREL-SALADIN, J. 2014. Is urbanisation in South Africa on a sustainable trajectory? Development Southern Africa, 31(5), pp. 675-691. https://doi.org/10.1080/037683 5X.2014.937524

TUROK, I. \& PARNELL, S. 2009.

Reshaping cities, rebuilding nations: The role of national urban policies. Urban Forum, 20(2), pp. 157-174.

TUROK, I. \& WATSON, V. 2001. Divergent development in South African cities: Strategic challenges facing Cape Town. Urban Forum, 12(2), pp. 119-138.

UN-HABITAT, 2004. Urban patterns for a green economy: Leveraging density. Nairobi: UN-Habitat.

VENTER, C., BIERMANN, S. \& VAN

RYNEVELD, M. 2004. Low-cost

housing location in South African

cities: Empirical findings on costs and benefits. Pretoria, Document Transformation Technologies cc.

WALTERS, J. 2013. Overview of public transport policy developments in South Africa. Research in Transportation Economics, 39(1), pp. 34-45. https:// doi.org/10.1016/j.retrec.2012.05.021

WATSON, V. 2008. Down to earth: Linking planning theory and practice in the 'Metropole' and beyond. International Planning Studies, 13(3), pp. 223-237. https://doi. org/10.1080/13563470802521408

WILSON, B. \& CHAKRABORTY, A. 2013. The environmental impacts of sprawl: Emergent themes from the past decade of planning research. Sustainability, 5(8), pp. 3302-3327. https://doi.org/10.3390/su5083302

WIRTH, L. 1938. Urbanism as a way of life. American Journal of Sociology, 44(1), pp. 1-24. https://doi. org/10.1086/217913 